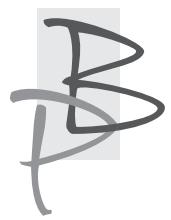

Kateřina Štroblová*

Faculty of Arts, University of Ostrava, Czech Republic

https://orcid.org/0000-0002-0206-0432

\title{
Whose Nostalgia is Ostalgia? \\ Post - Communist Nostalgia in Central-European Contemporary Art
}

Abstract: The paper is focused on a particular group of visual artists from Poland, Hungary, and the Czech and Slovak republics dealing with the issue of memory, history and nostalgia in their work. A common feature of their art is the perception of local space in its historical connotations, the exploration of historical content, causality reception, and the time-space orientation of man. Using space, with its physical and symbolic expression, is their strategy; a specific interest is the process of searching, changing or losing the identity in a historically complicated area of Central Europe. The article examines relations between collective memory, identity and nostalgia, captured in the artistic reflection and thus mirroring the actual state of a society.

Key words: Contemporary art, Central European art, history in art, nostalgia.

PhDr. Mgr. Kateřina Štroblová (*1984) is a Senior Lecturer in the Department of Theory and History of Fine Arts, Faculty of Fine Arts at the University of Ostrava (CZ). In her research she focuses on contemporary art practice of Central Europe. Based in Prague, she is also a freelance art reviewer and a curator of Luxfer Gallery, an independent art space and studio in Česká Skalice (CZ). 
Whose nostalgia is Ostalgia? is originally an essay title by Edit András ${ }^{1}$, an art historian from Hungary, writing about the New York exhibition of Eastern European art in 20112.

I borrowed the title for my paper because it is focused on a certain segment of contemporary Central and Eastern European art focusing on history including an undertone of nostalgia.

I will try to indicate here the most common artistic approaches to the topic and pick several examples among prolific contemporary artists.

Nostalgia for communist times - the so called ostalgia - is a widespread phenomenon in all of the countries of the former Eastern bloc. It has many variations - from collecting old everyday objects, reprising favourite communist films and series on TV, T-shirt prints with the hammer and sickle, special reeditions of food and drinks of that era etc. Some countries even have a special term for it (Titostalgia or Yugonostalgia in the former Yugoslavia, etc.).

There are many studies about ostalgia in different areas - cultural, political, sociological etc. ${ }^{3}$, but in the field of visual arts ${ }^{4}$, it is still not sufficiently reflected.

Nostalgia (the term is a mix of Greek "nostos" and "algos", "return home" and "longing") is longing for place or time that no longer exists or has never existed. It's a sentiment of loss and displacement ${ }^{6}$. The core of nostalgia (and of its Eastern version, ostalgia) lies in positive memories about the past: people miss it, but don't want it to return, nor do they want the old systems back. They

1 E. András, Whose Nostalgia Is Ostalgia? An Eastern Europe and Former Soviet Republics survey exhibition in the New Museum, New York, [online] https://www.springerin.at/en/2011/4/wessen-nostalgie-ist-die-ostalgie/ [accessed: 20 January 2020].

2 Ostalgia, curated by M. Gioni in New Museum, New York, 07/06/11-10/12/11.

3 There are several key texts as Charity Scribner, Requiem for Communism, Owen Hatherley, The Landscapes of Communism, Maria Todorova (ed.), Post-Communist Nostalgia, Mariusz Czepczyński, Cultural Landscapes of Post-Socialist Cities, Beverly James, Imagining Postcommunism etc.

4 Basically, any work produced in the countries of the former Eastern Bloc is often being called as „ostalgic“ - as in the aforementioned New Museum's Ostalgia exhibition (author's note).

5 The term was coined by Swiss physician Johannes Hofer in 1688 to describe a medical condition of soldiers longing for their homelands (author's note). Read more in Svetlana Boym, The Future of Nostalgia, London: Basic Books, 2002.

6 Ibid. 
play with the images of return, but only because they are absolutely certain that it will not be back. Nostalgia is an unsatisfiable wish in a certain way, and thus it is so strong, present and convincing?.

The key to understanding nostalgia is however the present, not the past. The strength of nostalgic feeling depends on the state of the society: the more problematic it is, the stronger nostalgic feeling is - to sum up, the more is the society disappointed ${ }^{8}$ with unfulfilled wishes and promises, the more nostalgic it is.

It is necessary to define the difference between nostalgia and calming memory of old happy times, which serve as a connection with the past and offers a feeling of continuity. For nostalgia, a certain underrating of the present and exaggerating the past is significant. Only some of the aspects of the past are pointed out, such as "safe and easy life", low prices, stable jobs, etc. Other significant features of the communist state - repressions, centrally planned economics, censorship, travelling restrictions - are out of sight or forgotten. The result is that the past seems to be resurrected and critical thinking about its heritage is left out. Nostalgia is collecting and preserving several elements of a fallen era, and the renewing of the reality in certain points seems to be possible9.

Nostalgia is considered to be a personal feeling, but there are several ideas that whole periods of history can be nostalgic, like the postmodern era ${ }^{10}$. If we can mark a single time period as nostalgic, it surely can be applicable to a certain spacial area, or a society segment.

In the countries of former Eastern bloc, diversities in social groups' nostalgia can be spot. There is the older generation, who of course spent most of their lifetime under socialism - they now suffer identity loss, they are retired,

\footnotetext{
7 M. Velikonja, Lost In transition, "East European Politics And Cultures“, 2009, 23 (4) p. 532.

Ibid.

9 N. Pancheva-Kirkova, Between Propaganda and Cultural Diplomacy: Nostalgia towards Socialist Realism in Post-Communist Bulgaria, [online] https://www.scribd.com/ document/220436391/Nina-Pancheva-Kirkova-Between-Propaganda-and-Cultural-DiplomacyNostalgia-Towards-Socialist-Realism-in-Post-Communist-Bulgaria [accessed: 25 January 2019].

10 Cf. F. Jameson, Postmodernism, or, The Cultural Logic of Late Capitalism, Durham: Duke University Press, 1992 and L. Hutcheon, Irony, nostalgia, and the postmodern, "Studies in Comparative Literature“, 2000, 30, pp. 189-207. Etc.
} 
usually in a bad financial situation, without ideals, and they are not young anymore, so longing for youth is a huge nostalgic factor.

Then there are people of the youngest generation, who are searching for their identity via current retro trends and some kind of "historical magic" narrative.

And then there is the generation in between, the so-called "generation X" in Western countries, but in Central and Eastern Europe it has a very specific position. They are on the edge of two historical times, stuck between past and future, with a specific nostalgia, sourced in their childhood memories and attempts to define their identity.

This generation is crucial in my research, where I focus on art, reflecting the social environment and changes. In the visual arts, a strong tendency to reflect the past is current: the so-called "historiographical turn" seems not to be spent yet. But a particular group of authors and works can be marked: those who reflect a socialist past in various ways and points of view, and thus the word nostalgia is on the daily menu while dipicting their work. Let me talk about several ways to explain this nostalgia and its principles in several images.

I have marked several categories or artistic approaches to the past, with a very nostalgic point of view: returns to visual culture elements, work with the issue of architecture and housing, re-contextualisation of past phenomena and documentary forms of reflection.

\section{Returns to visual culture elements}

For these returns, artistic use of aesthetic patterns of previous eras is significant. In our area of interest, those authors follow (socialist) modernist forms.

Returns to certain aspects of modernism - design, architecture and visual culture - has been a persisting trend of contemporary European art since the nineties. These early practicioners ${ }^{11}$ revisited classic modernist tropes as an object of fascination and criticism, a multiple and inconsistent entity. They have addressed modernism for various reasons, from formal attraction, nostalgia (for example for its commitment to social agendas) to failed ideological system $^{12}$.

11 e.g. Dominique Gonzalez-Foerster, Tobias Rehberger and others.

12 C. Bishop, Reactivating Modernism, "Parkett", 2013, vol. 92, pp. 146-153. 
Polish artist Paulina Olowska (*1976) mixes elements of western avantgardes with the eastern modernist style and socialist modernism, creating unique and very nostalgic images, implying lost utopian dreams.

In Covers from Morze (2009), she combined old magazine covers, creating tiny stories according to the pictures' themes: the man lighting his cigarette from the welding machine fire, and the sexy blonde woman bathing in the waves, which seems to be caused by the fire, etc. These lost fantasies of the proletariat reveal strange relationships between labour and culture, industry and soft pornography, similar to the atmosphere of communist Poland, all in the mist of nostalgia for the past ${ }^{13}$. The time period has been chosen purposedly: the year 1958 is the middle of four year rule of Władysław Gomułka, whose politics was later called "Gomułka's thaw", and 1980 - the beginning of the Solidarnosć movement in Gdańsk. Being the author's hometown, these covers document not only social events, but the period of her childhood as well, binding collective and personal memory together.

"Applied fantastic" is a 1959 term by the writer Leopold Tyrmand ${ }^{14}$ depicting the imitating of Western styles in socialist countries. In the eponymous painting series from 2010, Olowska was inspired by fashion magazines, imitating Western styles of dressing, together with card-like instructions for knitters with a certain model pictured, as they were popular in Poland at that time. Both female and male models are depicted in knitted sweaters in front of a neutral background or a winter landscape, and several painitngs are inscribed with the original and playful titles of the knitting patterns as well: Cake (Torcik), Bee (Psczola) or Clown (Klaun).

In these series, nostalgia is present in a most obvious way. However, it seems quite ambivalent in the work: it is a fascination with the aesthetic of that period and a kind of "optimistic amnesia" of the time, and on the other hand a desire for the Western lifestyle and a critique of contemporary consumerism. Both a certain deprivation and forcefully improvised elegance, and a contrast to mass production following the socialist era ${ }^{15}$ is expressed in the work.

13 J. Szupinska, Paulina Otowska's Covers from Morze (1958-80), [online] http://www.artslant.com/mia/articles/show/13265 [accesssed 1 February 2020].

14 D. Crowley, Warsaw, London: Reaktion Books, 2003, p. 123.

15 T. Williams, Paulina Otowska: Metro Pictures, “Art in America”, 2011, no. 2, p. 98. 


\section{Modernist architecture and housing in art}

Many of the contemporary artistic works reflect the past via space and its form for living - the architecture. They use architecture as a topic and method to culture survey. The artists from Central and Eastern Europe are facing the fact that social, political and economical legacy of socialism - their preferred issue - had found its expression primarily in architectonical structures. They reflect how history, collective memory and desires for the future are imprinted in urban space ${ }^{16}$.

Slovak artist Tomáš Džadoň (*1981) is such an example. Džadoň often uses architecture for various forms of interpretation: he reflects his own experience of his childhood, spent partly in a panel house block and partly at his grandma's country house. He explores local traditions together with socialist life phenomena, and the formative impact of both on personal and collective identity. $\mathrm{He}$ asks how are we able to deal with the fact of the constant destruction of traditions during the socialist era? According to Džadoň, tradition is a living element, bound together and influencing our present and thus the future as well.

The artist is very well aware of the fact that childhood nostalgia affects our view of the past, and his confrontations deal with this conscious and unconscious amnesia.

A dominant element in Džadoň's work is the panel house block, one of the symbols of the former regime - typical, often very low quality concrete architecture. A contrast between the panel house and traditional folk architecture is a huge issue in the artist's work.

His outstanding project Folk Architecture Monument (2013 - 2016) was realised in the city of Košice (SK). On the roof of a common 13-storey panel house three traditional Slovak wooden houses were installed. The question here - among many others - is whether the "ugly" panel house is inferior to traditional architecture, and whether we should deal with the fact that the panel house is gaining a traditional status as well.

Various possibilities of intepretation can also be found in Džadoň's installation I Have Lost The Instruction (2009), which consisted of 17 cardboard scale

16 L. Polyák, The Pavillions of Recollection. Architecture and Memory in Contemporary Eastern European Art, [in] N. Wendl, I. Wallace (eds.), Contemporary Art about Architecture: A Strange Utility, London: Routledge 2013, pp. 209-210. 


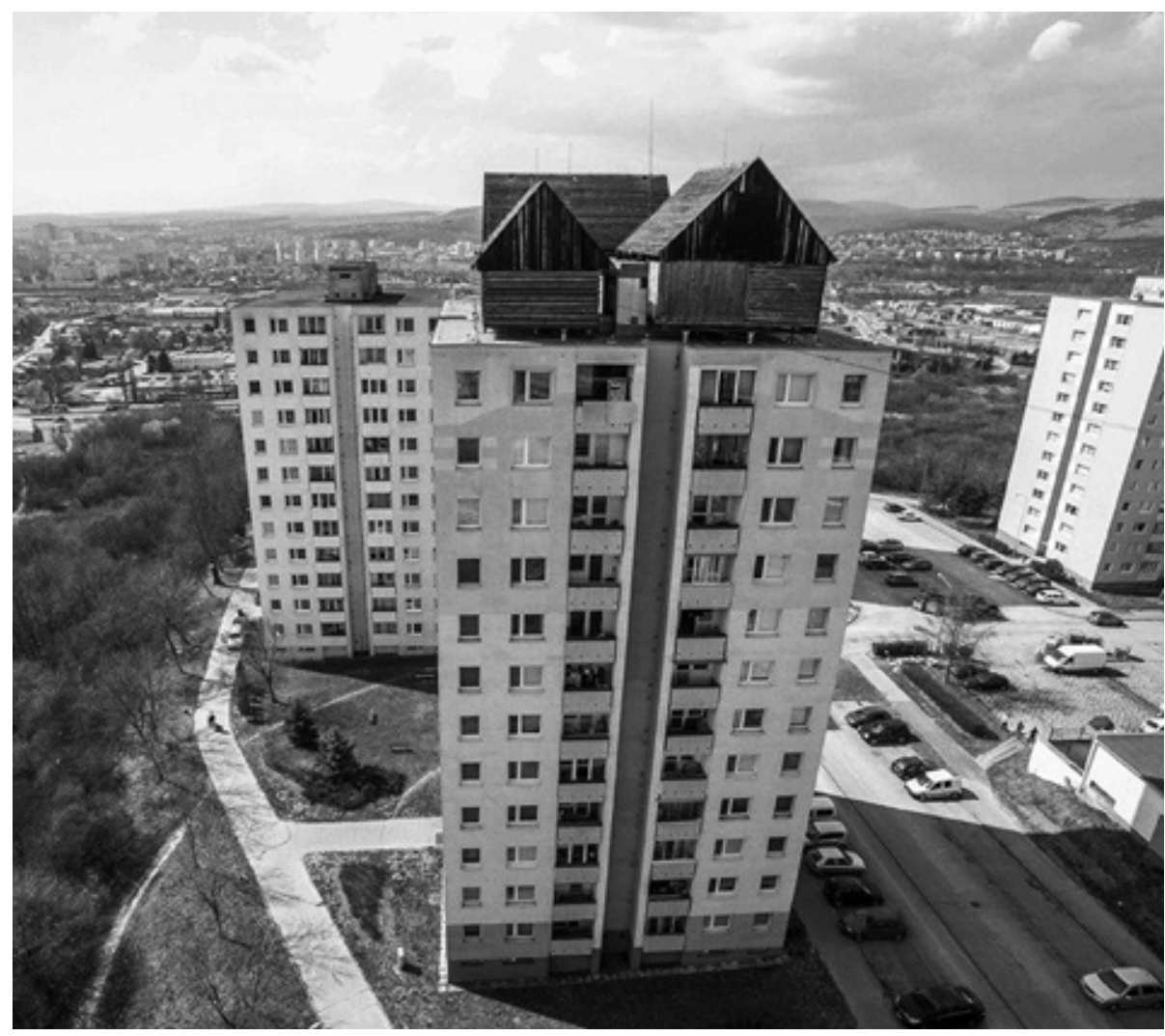

Tomáš Džadoň - Folk Architecture Monument (2013-2016) photo Szaszák György

models of panel house walls in full scales, with all the details, like balconies and windows. In fact, together it would form a real flat which the author had lived in as a child. Each part seems to be waiting for displacement and re-building in various combinations. A panel house is used as a time-layer and a forming element: it is a new village, a new wooden cottage. Thanks to this relativization of panel housing the artist is getting over a personal feeling of uprooting, questioning a searching for identity related to tradition, old or recent.

Polish author Julita Wójcik (*1971) works with tradition in a different way, although she works with local architectural contexts as well. Wójcik often explores the role of women and their stereotyping in contemporary society, comparing it with past eras. Although there is a certain form of criticism in her 
works, the ambition of most of them is far more simple: to praise common human work, everyday life, and things often escaping our attention despite being a creative factor of our everyday existence.

Understandability, the playfulness and lightness of her work often lead viewers to participate in it. Julita Wójcik works in a local context: her work is sourced in the Polish environment, in homely soil. However, its impact is widened into a global scale. By realising our own context we can make our world prettier and thus better.

In her art, the traditional handwork of all the previous generations of women, such as knitting or crocheting, takes an important role. One of her first crocheted artifacts was presented in a private show called Dreaming of a Provincial Girl in 2010, being an early manifestation of the "new banalism movement" in Poland, a tendency which can be observed in the seventies-born artists and is characterised by banal, common everyday issues ${ }^{17}$.

One of her imposant knitted works is Falowiec (2005 - 2006), a replica of the famous housing block in Gdańsk. Built in 1970 - 1973, it is the longest housing block in Europe with more than 6.000 inhabitants. Wójcik's Falowiec is a nostalgic connection between the past and today: the artist accented its monumentality, the absurd, inapropirate presence, the embodied bizarre ideal of communist architecture into a decorative object, visually attractive, enabling to transform the memories into something nice and in human proportions. She made some kind of mascot here. An unidentifiable object at first sight, seeming to be as similarly surreal as its original, immense mass of building material.

Wójcik reflected the problematics of the aestheticization of socialist-modernism in several other works. Video Wedutystka (The Vedutist, 2004) was a performance record. In Gdańsk, the autor, dressed in a typical frock and a headscarf, fictionally "painted" old block house facades. Her hand was led by an invisible voice, taking care that the imaginary colour covered all the marked fields. We can see here another attempt at object interiorization, similarly as in Falowiec, and its aesthetization.

The artist created a similar atmosphere in Sielanka (Idylle, 2004): the video depicts the author, dressed in the same way, lying on the grass and watching

17 M. Ujma, Sztuka krytyczna i co dalej? [in] M. Lewoc (ed.), Contemporary Identities: Current Artistic Creation in Poland, Szczecin 2004, p. 49. 
the sky, having a grass stalk in hand. Idyllic at first sight. But then we notice the totally non-idyllic background of the scene - old factory towers and chimneys, a relic of the former industrial era.

Very strong media echos and discussions were raised around Wójcik's performance called Potatoes Peeling (Obieranie ziemniaków) in Warsaw's Zachęta Gallery in 2001. The artist, sitting on a stool, dressed in a frock, peeled fifty kilos of potatoes during the action, talking with press and visitors at the same time.

This performance offered various interpretations. The first one is peeling potatoes seen as a traditional women's job, the predestination of women being responsible for everyday food preparation and household care. Potatoes have long been an essential part of Polish cuisine, so preparing them was an everyday task. The author thus identified herself with housewives, not only of today, but of several generation before ${ }^{18}$. Peeling potatoes is a boring, endless routine, and such was Zachęta's performance as well. Here is another - participative - context. There were many visitors who came to help the artist with peeling, some of them with their own peelers; a social scuplture was created there. The performance raised a great scandal, and it was questioned whether it could be considered art or not, and what should be presented in gallery space - especially in an institution like a state gallery.

\section{Re-contextualization of the past phenomena}

Another very common strategy in contemporary artistic practice is replacing or re-contextualization. Putting or transferring objects or ideas into different contexts enables connection of the past with the present, and finding a specific way to understand this transfer.

In the action of Polish artist Maciej Kurak (*1972), called The Space, a socialist grocery store was recreated on its original spot in the city centre of Poznań (2002). For one day, it was returned to the past. All details were recreated - the facade, house number, walls, interiors, even the goods like soap and exercise books, the shop assistant's uniform and the radio programme broadcasting. The installation divided the guests into two groups: one group who came to the opening couldn't find the gallery place; the others, elderly people

18 K. Sienkiewicz, Julita Wójcik, „,Obieranie ziemniaków“, [online] https://culture.pl/pl/dzielo/julita-wojcik-obieranie-ziemniakow [accessed: 16 February 2020]. 
who remembered the shop, thought that it was open again and were happy about it. The project was a kind of a sentimental or nostalgic way to the past, but posed important questions about the history of a certain place, our ability to connect with it, how do we react to its changes, etc.

Other examples of re-contextualization are several projects of the Hungarian duo Little Warsaw. The physical replacement of artifacts is their basic strategy for expressing a transfer of values, common interpretations, and tension between momuments and memory. In their famous action Instauratio (2004) they made a simple but monumental gesture: they moved a bronze statue from a small Southern Hungarian village to a gallery space in Amsterdam. The statue of János Szántó Kovács, a leader of the agrarian movement from the beginning of the 20th century, was created by a reputable sculptor, József Somogyi, in 1965, and we can call it a mild modernist statue typical for socialist production of that time. This act by Little Warsaw aroused great controversy among the Hungarian art scene, and they were criticised and accused of "desecration" of the statue and mocking its sculptor. But the aim of Little Warsaw was quite different: on one hand, it was an institutional critique showing different practice inside and outside museums and public space, and on the other hand pointing out recent attitudes to evaluation of the past. They revealed something which was forgotten, and together with that the scars of the past which were never fully healed. The question is - who has the right to dig out the past and re-contextualize the objects and ideas of the past today? Little Warsaw uncovered a very interesting phenomenon: a hidden mechanism of a society, whose aim is to preserve a certain status quo - or to get back something from the past, which is the key of nostalgia.

\section{Documentary forms as an interpretation of history}

The last point of view is the documentary mode in contemporary art, working primarily with found archived materials and confronting them with the current situation. Artistic documentary become a very prolific form in the historiographical turn current. To document means to collect different data, leading to interpretation ${ }^{19}$ of historical events or facts: history is depticted and interpreted

19 M. Foucault, The Archaeology of Knowledge and The Discourse of Language, New York: Pantheon Books, 1982, pp. 126-31. 
through the imagination of the author and the viewer. The documentary thus offers various possibilities of space and memory analysis ${ }^{20}$.

Documentary tendencies in the region of Central and Eastern Europe can be perceived as a medium to cognition and re-cognition of post-soviet situation $^{21}$. The authors document the background of their own culture and cultural past, so I call their approach as autoethnographical.

One of these authors is the Slovak photographer Lucia Nimcová $\left({ }^{*} 1977\right)$, who uses pictures found in the archives of institutions and personal archives as well. In these photographs she is searching for the history of not only her birthplace, but mainly the stories of local people and the changes of their lives in the time stream.

In one of her earlier series, Instant Women (2003), Nimcová focused on Central and Eastern European women of different age groups, their plans and dreams contrasting with the harsh reality they were living in. She observed the fragile moments of people's fates. Women who were - together with all the society - adapting to new, radically changed reality, who were searching for their own reality within traditional models and new situations. Their lives were absorbing fragments of the Western world's reality from television and magazines, idealized and the core of dreams that life could be similar, although the difference is so huge now. It may seem that somewhere below the everyday life surface everything stays the same, but principal human values, the way of thinking, are, in fact, shaking: the traditions are fading and disappearing, conflicts between generations are increasing, life is less close and more ambitious, as the artist stated ${ }^{22}$. In Instant Women, real women as well as the fictional ones from the TV screen are depicted, even the non-present ones, whose existence is marked only by the environment, such as an unmade bed. There are several motives repeating: skirts in motion, little girls dressed as princesses, brides in kitschy frocks, typical party food, grannies with grandchildren. Every image

20 J. Verwoert, Research and Display: Transformations of the Documentary Practice in Recent Art, [in] M. Lind, H. Steyerl (eds.), Reconsidering the Documentary and Contemporary Art \#1: The Greenroom, Berlin: Sternberg Press, 2008, pp. 201-205.

21 H. Weeks, Re-cognizing the post-Soviet condition: the documentary turn in contemporary art in the Baltic States, "Studies in Eastern European Cinema", 2010, vol. 1, pp. 57-70.

22 See more on: http://www.luco.sk/iw.htm. 
has its own atmopshere, though - melancholy and nostalgic after life like it was and how is should look.

Her powerful documentary series called Rusyns (from 2006 on) depicts the past and present of the Rusyn people, who were removed from their homes because of the construction of the Starina dam in the eighties. Seven villages in the area (Eastern Slovak region of Prešov) were destroyed due to this socialist project "for public welfare and the people", and people had to settle in their new homes in the nearby city of Humenné, mostly in newly constructed panel housing blocks, losing their identity, their bond with a place, and their memories as well. The artist, being one of the descendants of this Rusyn community, thus created not only a historical document, but recorded her own search for identity as well. She went through thousands of archive pictures, both in official archives and family ones, meeting different types of memories: the family ones (often being the only things preserved), and the ones from amateur or official photographers (using their skills for propaganda).

Expressing her feeling as a member of probably the last generation remembering a few things from the everyday rituals, spirituality and language of the Rusyn community, she attempts to preserve the disappearing culture. Young people do not keep the traditions, so they are doomed to vanish, and they are losing the connection with the older generation. Lucia Nimcová worked as a mediator or curator here: from the archives she mostly chose the pictures showing everyday family and village life. Then she invited several young Rusyn photographers to document the everyday life of contemporary families, and by confronting these two documentaries the past and present are bound together.

In another series, Unofficial (2006 - 2009), Nimcová combines archival and newly made pictures. She picked photographs showing life during the socialist era, created for official purposes: not only everyday life, but events such as local party meetings, choir performances, regional festivals or sports events. This series is unique research of changes of a certain space. In her newly made pictures, Nimcová focused on depicting today's life of the people from archival photographs. The older generation, more than twenty years after the fall of comunism, seem to live in a similar way: they are equally passive, indifferent and depressed. As the artist remarked: they are not living real life, but they live a life according to their memories. 
Archival materials are the core of the Hungarian author Zsolt Keserue's (*1969) work. His main genre is experimental videodocumentaries, focusing on man, his environment, and common, everyday problems and issues. $\mathrm{He}$ is interested in tiny matters, details, put together as mosaic pieces in a wider picture of society and interpersonal relationships - it is a kind of social probe into the local community.

His primal topic is mutual affection of the past and present. Always working within a specific context, a certain time, the artist follows the connection between place and history.

Lekerekitás (Rounding off, 2006) is a videodocumentary about personal and intimate space, namely about the life in socialist panel blocks. Situated in Budaörs, a suburb of Budapest, the documentary is constructed by interviews with the panel houses' inhabitants. We can't see the faces, nor do we know the questions posed. The participants become a part of the film via their anonymous stories ${ }^{23}$. The main aim of the artist is to find out why the people decided to live here: bad financial conditions, impossibility of finding other flat, the habit of many people living there since their childhood, or other reasons. They all agree that the inner space of the flat is very individual, and the documentary further follows very various attempts to build their personal living space, to define their own place within a collective, in physical and psychical ways as well.

Keserue's video Ki Volt Mátyás király? (Who Was King Mathias? 2008) is an interesting probe into contemporary society with the help of its historical reflexion. It captures a group of elderly people in a very cheap dirty bar in Budapest, drinking and discussing. The main issue of the debate is the personality and historical background of King Mathias Corvinus (1443-1490), who is still very popular in the country. He is a cultural phenomenon, about whom everybody can say a word. The talk begins with interpretations of tales and legends about the king, most of them very similar to those known in other countries as well (e.g. the emperor walked incognito among his people and tried to live like poor peasants). The reflection of historical facts becomes the bridge to the recent past and now. The simple question "Who was king Mathias?" uncovers the layers of collective memory. Deep and aching social problems are revealed: ide-

23 Z. Frazon, Modernity as Local Tradition - Subjective City Archive, [in] N. Alföldi, Z. Frazon, Keserue Zsolt: 23 monológ, Budapest: Paksi Keptár 2009, p. 25. 
alizing past eras, misinterpretation of historical events, negative feelings about the present, mythization and overrating certain social segments, like peasants.

The most monumental video work of Zsolt Keserue is Nagyólvasztó (Blast Furnace, 2008). This multi-layered fresco tries to catch the beginning and development of cultural life in Dunaújváros, probably the biggest living memento of socialism in Hungary. The city on the Danube riverside, founded in 1949, was settled as a starting point of Hungarian industrialization. Formerly Sztálinváros - Stalin's Town - it rose rapidly. Hand by hand with heavy industry, the city infrastructure developed as well. Is it possible to create any culture in an artificial city? Keserue's documentary traces these attempts in different storylines.

\section{Conclusion}

By marking several cathegories of artistic approaches concerning post-soviet period nostalgia I tried to illustrate them with specific works of various artists from Central Europe. Through different media, these authors create paintings, videos, installations or objects using elements from previous era: visual culture, architectonical structures, archive materials or real objects, which they replace or recontextualize to new circumstances.

All these artists articulate a generational feeling of unsettling, a permanent balancing between two regimes, two different worlds, not to be able to mark the better and the worse one, because both are a part of individuality. We can spot a common feature of their work, which is the perception of a local space in its historical connotations, exploring historical content, the reception of causality and time-space orientation of man. They focus on collective memory, and its metamorphosis and processes. A specific interest is the process of searching, changing or losing identity in a historically complicated area of Central Europe.

These artistic approaches are part of the so-called historiographical turn in contemporary art, which has been settled as a common trend since the nineties. The article is a contribution of how is history and specific experience of Central and Eastern Europe reflected in the current artistic tendencies. 


\section{References}

András, E. (2011). Whose Nostalgia Is Ostalgia? An Eastern Europe and Former Soviet Republics survey exhibition in the New Museum, New York. https://www. springerin.at/en/2011/4/wessen-nostalgie-ist-die-ostalgie/ (accessed 20 January 2020).

Bishop, C. (2013). Reactivating Modernism. Parkett, 92, 146-153.

Boym, S. (2002). The Future of Nostalgia. London: Basic Books.

Crowley, D. (2003). Warsaw, London: Reaktion Books.

Foucault, M. (1982). The Archaeology of Knowledge and The Discourse of Language. New York: Pantheon Books.

Frazon, Z. (2009). Modernity as Local Tradition - Subjective City Archive. In N. Alföldi, \& Z. Frazon, Keserue Zsolt: 23 monológ. Budapest: Paksi Keptár.

Hutcheon, L. (2000). Irony, nostalgia, and the postmodern. Studies in Comparative Literature, 30, 189-207.

Jameson, F. (1992). Postmodernism, or, The Cultural Logic of Late Capitalism. Durham: Duke University Press.

Ostalgia, curated by M. Gioni in New Museum, New York, 07/06/11 - 10/12/11.

Pancheva-Kirkova, N. (2014). Between Propaganda and Cultural Diplomacy: Nostalgia towards Socialist Realism in Post-Communist Bulgaria. https://www. scribd.com/document/220436391/Nina-Pancheva-Kirkova-Between-Propagandaand-Cultural-Diplomacy-Nostalgia-Towards-Socialist-Realism-in-Post-CommunistBulgaria (accessed 25 January 2019).

Polyák, L. (2013). The Pavillions of Recollection. Architecture and Memory in Contemporary Eastern European Art. In N. Wendl, \& I. Wallace (Eds.), Contemporary Art about Architecture: A Strange Utility (pp. 209-210). London: Routledge.

Sienkiewicz, K. (2011, March). Julita Wójcik, „Obieranie ziemniaków“. https://culture.pl/pl/dzielo/julita-wojcik-obieranie-ziemniakow (accessed 16 February 2020).

Szupinska, J. (2009). Paulina Ołowska's Covers from Morze (1958-80). http://www. artslant.com/mia/articles/show/13265 (accesssed 1 February 2020).

Ujma, M. (2004). Sztuka krytyczna i co dalej? In M. Lewoc (Ed.), Contemporary identities: Current artistic creation in Poland (p. 49). Szczecin.

Velikonja, M. (2009). Lost In transition. East European Politics And Cultures, 23 (4), 532. Verwoert, J. (2008). Research and Display: Transformations of the Documentary Practice in Recent Art. In M. Lind, \& H. Steyerl (Eds.), Reconsidering the Docu- 
Kateřina Štroblová, Whose Nostalgia is Ostalgia? Post - Communist Nostalgia...

mentary and Contemporary Art \#1: The Greenroom (pp. 201-205). Berlin: Sternberg Press.

Weeks, H. (2010). Re-cognizing the post-Soviet condition: The documentary turn in contemporary art in the Baltic States. Studies in Eastern European Cinema, 1, 57-70.

Williams, T. (2011). Paulina Ołowska: Metro Pictures. Art in America, 2, 98. 